\title{
STUDI HUBUNGAN KARAKTER MORFOLOGI, ANATOMI, DAN MOLEKULER TERKAIT POTENSI KADAR KATEKIN PADA TANAMAN GAMBIR ( Uncaria gambir (Hunter) Roxb)
}

\section{STUDIES OF MORFOLOGY, ANATOMY, AND MOLECULAR CHARACTERS AND ITS RELATIONSHIP THE CATECHIN PRODUCTION ON GAMBIER PLANT (Uncaria gambir (Hunter) Roxb))}

\author{
Istino Ferita*), Jamsari*), Irfan Suliansyah*), dan Gustian*) \\ *) Staf Pengajar Jurusan Budidaya Pertanian, Fakultas Pertanian Universitas Andalas Padang \\ Kampus Limau Manis Unand Padang, 25163 Sumatera Barat \\ Telp.0751-72776. Email: istinoferita@yahoo.com. HP: 08126644761
}

\begin{abstract}
Research on the relationship between morphology, anatomy, and molecular characters and potency of catechin production on gambier plant (Uncaria gambier (Hunter) Roxb.) was performed during April 2009 to Mey 2011. This research was aimed to identify some characters having tight correlation with the potency catechin production. Whole experiments were conducted in the three stages consisted of collection and selection of gambier population segregating for high and low levels of catechins production, isolation and purification of specific DNA fragments relating to the levels of catechins production, and designing of specific primer combinations associating to the potency for high levels of catechin production. Field studies was carried out at the experimental station of faculty of agriculture Andalas University. Main laboratory analysis was performed at Lab of Biotechnology and Plant Breeding Faculty of agriculture Andalas University. Some additional analysis were done in some labs distributing at Andalas University areas.

Morphological and anatomical data collected from observations were analyzed using descriptive methods. Meanwhile data from molecular analysis was accessed by means of Random Amplified Polymorphism DNA (RAPD) technique. Specific RAPD fragmenst linking with catechin production level were further analysis via cloning and sequencing, in order to identify their nucleotide sequences. After performing some sequence analysis and comparing for their homology information some sets of primer pairs were designed. The designed primer pair sets were checked for their compatibility using their original genome and some segregating population.

The research concluded that leaf colour particularly red colour indicated tightly link with the levels of catechins production. Finally, a specific primer pair namely Udtg3 (5'-CAGATCCTTTGCCACACTGA-3 ') and Udtg4 (5'-CGTA CCTGCCAA CATAACAG - 3 ') was succesfully designed and could be used as marker for catechin productin level. After testing step with the segregating population using different genetic backgorund the accuracy of the designed primer pair could reach $41,7 \%$. However, this marker could be used in the Marker Assisted Selection (MAS) system for gambir breeding program.
\end{abstract}

Key Word : gambier, RAPD, specific primers, and catechin 


\section{PENDAHULUAN}

Tanaman gambir (Uncaria gambir (Hunter) Roxb.) merupakan salah satu komoditas ekspor hasil perkebunan rakyat yang bernilai ekonomi tinggi dan prospektif untuk diusahakan secara komersial mengingat kegunaannya yang beragam. Getah gambir terutama mengandung senyawa katekin yang sangat dibutuhkan dalam industri-industri farmasi, kosmetik, batik, cat, dan lain-lain.

Di Indonesia tanaman gambir sebagian besar tersebar dan diusahakan di Sumatera Barat. Pada tahun 2006 tercatat produksi gambir di Sumatera Barat yaitu 12.973 ton, sedangkan pada tahun 2009 menjadi 13.897 ton. Pada tahun 2006 volume ekspor gambir Indonesia tercatat 15.630 ton, meningkat pada tahun 2009 menjadi 18.297 ton dengan nilai ekspor US \$ 13.760 tahun 2006, dan meningkat pada tahun 2009 menjadi US \$ 38,038 (Badan Pusat Statistik, 2010). Produksi gambir Indonesia diekspor ke negara-negara seperti: India, Jerman, Pakistan, Taiwan, dan Singapura. Umumnya gambir yang diekspor memiliki kadar katekin di bawah $75 \%$.

Kendala dalam pengembangan tanaman gambir adalah rendahnya produktivitas. Roswita (1990) dan Dinas Perkebunan Sumatera Barat (1998) menyatakan bahwa produktivitas tanaman gambir rakyat berkisar antara $400 \mathrm{~kg}-600 \mathrm{~kg}$ getah kering per ha, sementara secara teoritis potensi hasil tanaman gambir dapat mencapai $2.100 \mathrm{~kg}$ getah kering per ha. Hal ini disebabkan pada budidaya tanaman gambir belum menggunakan kultivar unggul dan bermutu. Penggunaan kultivar unggul merupakan faktor yang sangat menentukan dalam produktivitas suatu tanaman.

Memperoleh kultivar unggul tanaman gambir dengan kandungan katekin tinggi, merupakan suatu upaya yang dapat dilakukan dalam memperbaiki produktivitas dan mutu produk gambir. Justru itu, diperlukan pendekatan untuk mengetahui tanaman gambir yang mempunyai karakter-karakter morfologi dan genetis (molekuler) yang berpotensi katekin tinggi. Namun upaya tersebut menghadapi kendala, antara lain tidak tersedianya cara yang dapat digunakan untuk mendeteksi gambir dengan potensi katekin tinggi pada fase tanaman muda (bibit). Keberhasilan karakterisasi dan penentuan potensi genetik kadar katekin pada populasi tanaman gambir sangat ditentukan oleh kemampuan indentifikasi dini tentang keberadaan fragmen penciri katekin tinggi. Ketersediaan sistem diagnosa yang akurat dan cepat merupakan suatu 
prasyarat penting demi kelancaran sistem deteksi dini pada tanaman gambir yang mencirikan potensi genetik kadar katekin tinggi.

Teknik molekuler seperti RAPD (Random Amplified Polymorphic DNA) dapat digunakan untuk mendukung kegiatan pemuliaan tanaman, seperti identifikasi karakter-karakter spesifik melalui fingerprinting untuk tanaman gambir. Identifikasi pita-pita spesifik akan bermanfaat dalam identifikasi karakter tertentu seperti kadar katekin.

RAPD merupakan salah satu teknik fingerptining yang dikembangkan dari teknik PCR (Polymerase Chain Reaction) yaitu amplifikasi DNA secara in vitro yang mampu menggandakan DNA dalam jumlah jutaan kali dari jumlah semula. Teknik tersebut memiliki beberapa keunggulan dibandingkan dengan metode hibridisasi, salah satunya adalah tidak perlu menggunakan bahan radioaktif seperti yang digunakan dalam proses hibridisasi, sistem analisisnya cepat, sensitifitas tinggi, dan dapat mengidentifikasi organisme dengan jumlah yang sedikit (Babaloka, 2003; Jamsari, et al, 2004., Lee, et al., 1997; Lopez, et al., 2003; Pastrik and Rainey,1999). Sayangnya teknik RAPD memiliki beberapa kelemahan, antara lain adalah: sangat sensitif terhadap perubahan kondisi sehingga memberikan hasil yang kurang konsisten. Yu dan Pauls, (1992) menyatakan bahwa banyak faktor yang mempengaruhi ketidakstabilan dan sensitifitas penanda RAPD seperti rasio templet DNA dan primer, konsentrasi ion Mg dan Taq-Polymerase yang digunakan dan jenis mesin PCR yang dipakai, serta rendahnya suhu annelling dan pendeknya primer RAPD yang digunakan ( Yang, et al, 1996).

Resolusi dan reliabilitas pola pita RAPD bukan saja ditentukan oleh primer dalam PCR, tetapi juga dipengaruhi oleh kualitas gel, kondisi running gel, lamanya separasi fragmen dalam gel, serta prosedur laboratorium (Qi dan Lindhout, 1979). Berkaitan dengan fungsinya sebagai Marker Asisted Selection (MAS), penanda RAPD yang sudah terbukti terkait dengan sifat tertentu dapat dikonversi kedalam sistem sequens characterized amplified region (SCARs) (Paran, et al, 1998), serta sistem STS dan CAPs.

Sistem penanda STS (Sequence Tagged Sites) yaitu sistem penanda yang sudah berbasis pada informasi sekuen DNA. Primer yang didesain dapat dikembangkan dari fragmen spesifik yang merupakan penciri khusus kadar katekin tinggi. Untuk 
keperluan itu beberapa fragmen spesifik yang diperoleh dari fingerprinting berbasis RAPD sebagai penciri katekin tinggi dapat dianalisis lebih lanjut, yakni kloning fragmen RAPD ke dalam vektor pGem T Easy, yang dilanjutkan dengan sekuensing, dan pendesainan primer spesifik.

Sasaran yang hendak dicapai dalam penelitian ini, secara keseluruhan adalah dihasilkannya suatu metode deteksi secara dini (lebih awal) pada tanaman gambir sejak pada fase bibit, yang mempunyai potensi kadar katekin tinggi. Jika hal ini dapat dilakukan maka langkah awal yang dapat dilakukan dalam jangka pendek adalah memperbanyak tanaman yang sudah diketahui berkadar katekin tinggi tersebut secara vegetatif, baik konvensional seperti stek, cangkok, dan rundukan, maupun dengan kultur jaringan.

Tujuan penelitian ini adalah :

1. Untuk mendapatkan informasi karakter-karakter morfologi, anatomi, maupun karakter molekuler yang dapat dijadikan sebagai penciri tanaman gambir yang berpotensi kadar katekin tinggi

2. Untuk mendapatkan informasi sekuen DNA dari fragmen-fragmen spesifik yang terkait dengan potensi kadar katekin tinggi.

3. Untuk menghasilkan kombinasi primer spesifik terkait dengan potensi berkadar katekin tinggi

4. Untuk mendapatkan tingkat akurasi primer spesifik dalam menghasilkan sistem metode deteksi dini pada kegiatan seleksi tanaman gambir yang terkait potensi berkadar katekin tinggi dalam upaya peningkatan produktivitas tanaman gambir.

\section{II.BAHAN DAN METODE PENELITIAN}

\subsection{Tempat dan Waktu}

Pengamatan data karakter morfologi tanaman gambir dilaksanakan di Kebun Koleksi Gambir Fakultas Pertanian Universitas Andalas Padang. Analisis kadar katekin dilakukan di Laboratorium Fisiologi Tanaman Fakultas Pertanian, dan Laboratorium Fakultas Teknologi Pertanian Universitas Andalas. Pengamatan struktur anatomi daun dilakukan di Laboratorium Fisiologi Tumbuhan IPB Bogor. Percobaan 
isolasi DNA, amplifikasi PCR, dan kloning DNA dilakukan di Laboratorium Bioteknologi dan Pemuliaan Tanaman Fakultas Pertanian Universitas Andalas Padang.. Sedangkan kegiatan sekuensing dilakukan di Lembaga Biologi Molekuler Eijkmann Jakarta. Secara keseluruhan penelitian dilaksanakan selama 25 bulan yakni mulai April 2009 sampai dengan Mei 2011

\subsection{Bahan dan Alat.}

Bahan tanaman yang digunakan dalam kegiatan penelitian ini adalah empat tipe tanaman gambir (Udang, Cubadak, Riau Gadang, dan Riau Mancik) yang terdapat di kebun koleksi tanaman gambir Fakultas Pertanian. Bahn kimia yang digunakan antara lain; etil asetat (p.a), CTAB, $\mathrm{NaCl}$, Tris, $\mathrm{HCl}$, Ethanol (p.a), Ethidiumbromida, Phenol, Chloroform (p.a), Isoamyl alcohol, NaOH $\beta$-Mercaptoethanol, RNAse, RTG-PCR Kit (GE,USA), dd $\mathrm{H}_{2} \mathrm{O}$ standard PCR, dan primer RAPD dari operon dan lain-lain.

Alat-alat yang dipakai antara lain: UV-VIS spektrofotometer ultra violet (Genesis-UV), timbangan analitik, kurvet kuarsa, hot plate magnetic stirrer, cawan jangka sorong, busur, spidol, pena, pensil, colour chart (Munsell Color Charts for Plant Tissue), mesin PCR (Biometra-Jerman), unit elektrophoresis (Mupid-ExJepang), gel documentation system (Cybertech-Jerman), UV-Transluminator (Biometra-Jerman) dan lain-lain

\subsection{Metodologi Penelitian}

\subsubsection{Identifikasi dan Karakterisasi Morfologi, Anatomi, dan Molekuler}

\subsubsection{Identifikasi Morfologi dan Anatomi.}

Kegiatan identifikasi dan karakterisasi dimulai dengan melakukan analisis kadar katekin dari tanaman sampel. Untuk menentukan kadar ketekin digunakan metoda dan rumus perhitungan Ciba-Geigy (SP-SMP-377-1985). Karakterisasi morfologi mengacu kepada Tjitrosoepomo (1986), dan mengamati karakter daun (9 karakter), cabang (7 karakter), bunga (4 karakter), buah (6 karakter), dan komponen hasil (5 karakter). Struktur anatomi diamati terhadap 7 karakter ; kutikula (atas dan bawah), epidermis (atas dan bawah), palisade, spons, dan tebal daun, pada dua kelompok tanaman gambir tipe Udang kadar katekin tinggi dan kadar katekin rendah. 


\subsubsection{Analisis Data}

Data hasil pengamatan terhadap karakter-karakter morfologi dan stuktur anatomi ditampilkan dalam bentuk tabel, gambar dan data dianalisis secara deskriptif. Untuk melihat hubungan antara kadar katekin dengan beberapa karakter morfologi dan antomi dilakukan analisis regresi menggunakan program perangkat lunak statistix8, PAST program.

\subsubsection{Karakterisasi Molekuler dengan Differensiasi Fingerprinting RAPD}

Kegiatan dimulai dengan melakukan isolasi DNA genom tanaman gambir tipe Udang. Seleksi primer RAPD (98 primer) dilakukan terhadap kelompok (pool) Udang katekin tinggi dan Udang katekin rendah. Pembentukan pool berdasarkan nilai kadar katekin, yaitu $\leq 15 \%$ adalah pool katekin rendah yang terdiri dari U5, U15, U16, U21, dan $\mathrm{U} 22$, dan $>15 \%$, adalah pool katekin tinggi yang terdiri dari U7, U8, U12, U13, dan U14.. Primer RAPD yang memberikan polimorfisme antara pool katekin tinggi dan pool katekin rendah selanjutnya diuji pada tingkat seleksi individu penyusun pool.

\subsubsection{Purifikasi, Kloning, dan Sekuensing Fragmen Spesifik Terkait Potensi Kadar Katekin Tinggi}

\subsubsection{Isolasi dan Purifikasi Fragmen Spesifik}

Isolasi dan purifikasi dilakukan terhadap fragmen-fragmen RAPD target yang memperlihatkan karakter spesifik, artinya fragmen tersebut dapat digunakan sebagai penciri khusus dari genotipe gambir terkait potensi kadar katekin tinggi. Kegiatan purifikasi dilakukan menggunakan kit purifikasi (Promega-USA). Fragmen target hasil purifikasi selanjutnya digunakan sebagai templet pada kegiatan reamplifikasi dengan primer RAPD yang sama.

\subsubsection{Kloning dan Sekuensing Fragmen Terkait Potensi Katekin Tinggi.}

Produk PCR (hasil purifikasi) diklon menggunakan vektor plasmid pGem TEasy (Promega-USA). Reaksi ligasi menggunakan prosedur sebagaimana disarankan oleh promega (Promega-USA). Transformasi plasmid kedalam inang E.coli dilakukan menggunakan metode heat shock (Sambrook and Russell ( 2001). Seleksi transformans dilakukan pada media Luria Bertani padat yang diberi tambahan 
antibiotik ampicilin, IPTG, dan $X$-Gal. Produk rekombinan diseleksi menggunakan sistem blue-white selection.

Isolasi DNA plasmid dilakukan secara mini preparasi menggunakan metode quick and dirty (Birnboim and Doly, 1979). DNA hasil transformasi yang mengandung fragmen yang telah disisipi oleh plasmid, selanjutnya diuji menggunakan amplifikasi PCR dengan primer universal T7 dan SP6. Amplifikasi menggunakan RTG-PCR kit (Promega USA).

Kegiatan sekuensing DNA dilakukan di Lembaga Biologi Molekuler Eijkmann Jakarta, mengikuti metode Sanger, et al, (1970). Sekuen produk sekuensing dianalisis menggunakan program BLAST (Basic Local Allignment Search Tool) yang dapat diakses melalui internet : http://www.ncbi.nlm.nih. gov/BLAST.

\subsubsection{Desain Primer dan Uji Akurasi Sistem Penanda}

Disain primer dilakukan dengan menggunakan software Primer3 yang diakses secara on line di internet ((http://frodo.wi.mit.edu/primer3.2010). Primer yang disintesis selanjutnya diuji terhadap DNA genom awal, dengan melakukan optimasi pada suhu annealingnya.

Selanjutnya dilakukan pengujian tingkat akurasi primer spesifik hasil desain. Pengujian kombinasi primer ini dilakukan terhadap semua sampel tanaman gambir tipe Udang hasil koleksi (24 tanaman). Tingkat akurasi primer (dalam persentase) dapat dihitung dengan menggunakan rumus umum berikut. Tingkat keberhasilan primer yang diuji dinyatakan sebagai berikut:

Tingkat Akurasi $=\underline{\text { Jumlah sampel dengan produk sesuai harapan }}$ X 100\% Jumlah sampel yang diuji

\section{III.HASIL DAN PEMBAHASAN}

\subsection{Identifikasi dan Seleksi Populasi Gambir Berpotensi Kadar Katekin Tinggi dan Rendah}

Umunya hasil identifikasi dan seleksi terhadap 4 tipe tanaman gambir, menunjukkan nilai kadar katekin yang bervariasi. Kadar katekin tipe Udang lebih tinggi dibandingkan dengan 3 tipe lainnya (Tabel 1). Rata-rata kadar katekin tipe 
Udang 25,89\%, dimana nilai ini jauh lebih tinggi dibandingkan dengan tipe Cubadak (12,81\%), Riau Gadang (18,11\%), dan Riau Mancik (16,95\%).

Tabel 1. Persentase kadar katekin empat tipe tanaman gambir

\begin{tabular}{ccccc}
\hline \multirow{2}{*}{ Ulangan } & \multicolumn{4}{c}{ Persentase Kadar Katekin $(\%)$} \\
\cline { 2 - 5 } & T. Udang & T. Riau Mancik & T.Riau Gadang & Cubadak \\
\hline 1 & 22,95 & 17,60 & 18,79 & 9,02 \\
2 & 27,74 & 15,75 & 27,39 & 12,69 \\
3 & 24,07 & 3,18 & 17,05 & 12,00 \\
4 & 20,00 & 27,50 & 9,72 & 17,22 \\
5 & 14,15 & 33,88 & 19,50 & 13,04 \\
6 & 17,22 & 12,01 & 25,10 & 10,40 \\
7 & 35,17 & 16,35 & 12,69 & 17,03 \\
8 & 45,87 & 9,37 & 14,70 & 11,09 \\
\hline Kisaran & $14-45 \%$ & $3-33 \%$ & $9-27 \%$ & $9-17 \%$ \\
\hline Rata-rata & $25,89 \%$ & $16,95 \%$ & $18,11 \%$ & $12,81 \%$ \\
\hline
\end{tabular}

Terjadinya perbedaan nilai kadar katekin dipengaruhi oleh banyak faktor, baik yang menyakut pemeliharaan seperti tindakan pemupukan, dan pengendalian gulma, maupun yang berhubungan dengan tempat tanaman gambir dibudidayakan, yakni yang berhubungan dengan dataran rendah dan dataran tinggi. Fauza, et al (2010), menyatakan bahwa kadar katekin tipe Udang dari beberapa daerah di Sumatera Barat (7 lokasi daerah) cukup bervariasi. Lokasi Halaban mempunyai nilai kadar katekin lebih rendah yaitu 20,15\%. Lokasi Siguntur rata-rata kadar katekinnya adalah 46,87\%. Terlihat kecendrungan bahwa faktor ketinggian tempat mempengaruhi terhadap nilai kadar katekin yang diperoleh.

\subsection{Kajian Karakter Morfologi dan Anatomi}

\subsubsection{Karakterisasi Morfologi}

Pengamatan morfologi terhadap beberapa karakter menunjukkan perbedaan yang mengindikasikan bahwa perbedaan tersebut disebabkan oleh faktor genetik. Karakter panjang dan lebar helaian daun pada keempat tipe gambir menunjukkan angka yang hampir sama, demikian juga dengan karakter panjang tangkai daun dan diameter tangkai daun (Tabel 2). 
Tabel 2. Karakteristik morfologi dan komponen hasil empat tipe gambir yang diamati nilai rata-rata pada 48 tanaman

\begin{tabular}{|c|c|c|c|c|c|}
\hline \multirow[b]{2}{*}{ No } & \multirow{2}{*}{ Karakter } & Udang & Cubadak & R.mancik & R. Gadang \\
\hline & & Rata2 \pm Sd & Rata2 \pm Sd & Rata $2 \pm$ Sd & Rata $2 \pm$ Sd \\
\hline \multicolumn{6}{|c|}{ a) Daun } \\
\hline 1 & Panjang daun $(\mathrm{cm})$ & $11,99 \pm 1,61$ & $11.7 \pm 1,84$ & $10,58 \pm 1,39$ & $10,98 \pm 0,84$ \\
\hline 2 & Lebar daun $(\mathrm{cm})$ & $6,05 \pm 0,47$ & $6,43 \pm 0,72$ & $5,82 \pm 0,72$ & $5,79 \pm 0,55$ \\
\hline 3 & Panjang tangkai daun $(\mathrm{cm})$ & $0,8 \pm 0,12$ & $1,15 \pm 0,16$ & $0,84 \pm 0,22$ & $0,8 \pm 0,05$ \\
\hline 4 & Diameter tangkai daun $(\mathrm{cm})$ & $0,23 \pm 0,02$ & $0,21 \pm 0,03$ & $0,19 \pm 0,04$ & $0,22 \pm 0,03$ \\
\hline 5 & Tebal daun $(\mathrm{mm})$ & $0,36 \pm 0,06$ & $0,18 \pm 0,03$ & $0,29 \pm 0,15$ & $0,17 \pm 0,03$ \\
\hline 6 & Bentuk helaian daun & Oval & Oval & Obl & Obl \\
\hline 7 & Basis & Acu & Acu & Acu & Acu \\
\hline 8 & Apek & Acu & Acu & Acu & Acu \\
\hline 9 & Warna daun *) & merah & hj muda & hj tua & hj tua \\
\hline \multicolumn{6}{|c|}{ b) Cabang } \\
\hline 10 & Panjang ranting $(\mathrm{cm})$ & $49,1 \pm 8,66$ & $52,9 \pm 9,57$ & $46,02 \pm 6,87$ & $52,68 \pm 12,2$ \\
\hline 11 & Panjang ruas $(\mathrm{cm})$ & $6,46 \pm 1,01$ & $7,0 \pm 1,30$ & $6,3 \pm 1,03$ & $6,6 \pm 0,86$ \\
\hline 12 & Jumlah ruas (buah) & $7,38 \pm 1,30$ & $8,09 \pm 1,19$ & $6,9 \pm 1,29$ & $7,5 \pm 1,37$ \\
\hline 13 & Sudut cabang (o) & $65,6 \pm 4,38$ & $70,6 \pm 5,76$ & $65,0 \pm 5,3$ & $71,4 \pm 4,33$ \\
\hline 14 & Diameter ranting $(\mathrm{cm})$ & $0,38 \pm 0,04$ & $0,38 \pm 0,14$ & $0,34 \pm 0,06$ & $0,38 \pm 0,04$ \\
\hline 15 & Jumlah kait (buah) & $1,50 \pm 1,05$ & $2,59 \pm 0,57$ & $0,18 \pm 0,02$ & $1,5 \pm 0,02$ \\
\hline 16 & Warna cabang *) & hj coklat & hj coklat & hj tua & hj tua \\
\hline \multicolumn{6}{|c|}{ c) Bunga } \\
\hline 17 & Warna bunga *) & hj mrh & hj mrh tua & hj tua & hj tua \\
\hline 18 & Diameter bunga $(\mathrm{cm})$ & $5,01 \pm 0,5$ & $5,28 \pm 0,56$ & $4,15 \pm 0,39$ & $4,48 \pm 1,25$ \\
\hline 19 & Panjang tangkai bunga $(\mathrm{cm})$ & $3,77 \pm 0,82$ & $3,73 \pm 0,88$ & $3,38 \pm 0,7$ & $2,16 \pm 0,42$ \\
\hline 20 & Diameter tangk bunga $(\mathrm{cm})$ & $0,23 \pm 0,05$ & $0,26 \pm 0,05$ & $0,18 \pm 0,02$ & $0,19 \pm 0,02$ \\
\hline \multicolumn{6}{|c|}{ d) Buah } \\
\hline 21 & Panjang tangk buah $(\mathrm{cm})$ & $2,8 \pm 0,35$ & $3,27 \pm 0,42$ & $1,75 \pm 0,32$ & $2,19 \pm 0,37$ \\
\hline 22 & Diameter tangk buah $(\mathrm{cm})$ & $0,25 \pm 0,02$ & $0,26 \pm 0,03$ & $0,25 \pm 0,02$ & $0,24 \pm 0,02$ \\
\hline 23 & Warna buah muda*) & hj mrh & hj tua & hj tua & hj tua \\
\hline 24 & Warna buah masak *) & hj cok & cok tua & cok hit & cok hit \\
\hline 25 & Jumlah polong/tangkai (bh) & $72,2 \pm 12,2$ & $73,3 \pm 5,51$ & $62,9 \pm 7,98$ & $62,06 \pm 13,6$ \\
\hline 26 & Panjang polong $(\mathrm{cm})$ & $3,45 \pm 0,40$ & $3,15 \pm 0,42$ & $3,07 \pm 0,24$ & $3,19 \pm 0,24$ \\
\hline \multicolumn{6}{|c|}{ e) Komponen Hasil } \\
\hline 27 & Jumlah cabang/batang(bh) & $10,0 \pm 3,09$ & $5,5 \pm 1,32$ & $6,25 \pm 2,5$ & $5,0 \pm 1,0$ \\
\hline 28 & Jumlah ranting/cabang(bh) & $10,8 \pm 2,99$ & $13,5 \pm 2,84$ & $11,0 \pm 2,43$ & $13,2 \pm 4,4$ \\
\hline 29 & Jumlah daun/ranting (bh) & $13,2 \pm 2,24$ & $15,5 \pm 2,14$ & $11,06 \pm 2,04$ & $13,9 \pm 3,4$ \\
\hline 30 & Berat 1 helai daun $(\mathrm{g})$ & $1,56 \pm 0,54$ & $2,51 \pm 0,72$ & $1,65 \pm 0,58$ & $2,13 \pm 0,41$ \\
\hline 31 & Rendemen hasil (\%) & $6,7 \pm 0,39$ & $5,87 \pm 0,58$ & $6,12 \pm 0,50$ & $5,8 \pm 0,8$ \\
\hline
\end{tabular}

Keterangan : $\mathrm{Ov}=$ oval, $\mathrm{Obl}=$ oblongus, $\mathrm{Ac}=$ Acutus, $\mathrm{Acu}=$ acuminatus, $\mathrm{hj}=$ hijau, $\mathrm{mr}=$ merah, $\mathrm{md}=$ muda, cok $=$ coklat, hit $=$ hitam

*) = Penentuan warna menggunakan standar referensi colour chart (Munsell Color Charts for Plant Tissue)

(Tipe Udang 24 tanaman, T.Cubadak, T.Riau Gadang, T.Riau Mancik masing-masing 8 tanaman)

Karakter warna daun merupakan salah satu karakter yang dapat dilihat secara morfologi untuk membedakan antara satu tanaman dengan tanaman lainnya dalam mengelompokkannya kepada empat tipe yang ada selama ini (Gambar 1). Namun demikian perbedaan warna tersebut tidaklah tegas, dan mempunyai variasi yang cukup sulit untuk diperhatikan. 


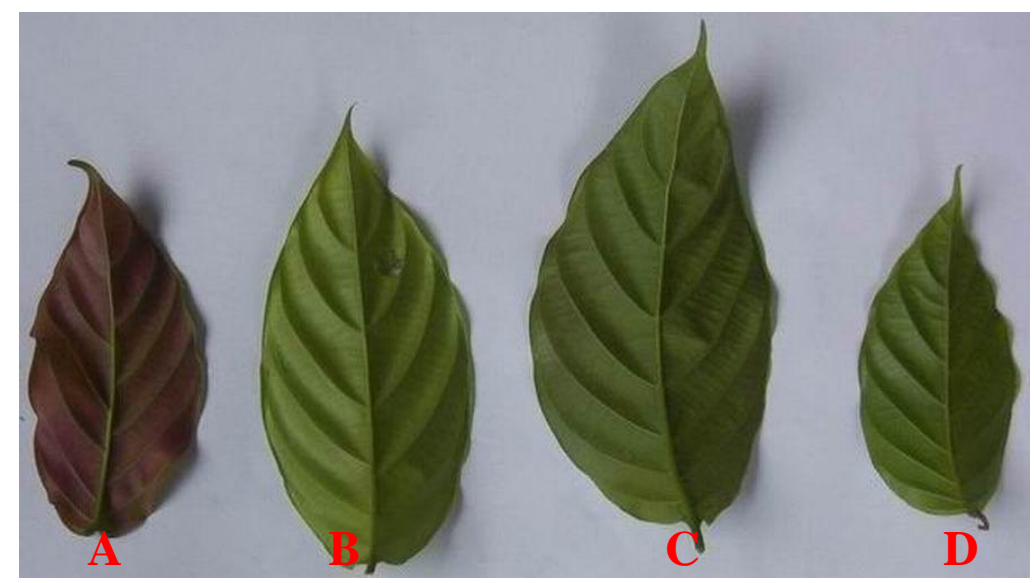

Gambar 1.Penampilan helaian daun gambir, $\mathrm{A}=$ tipe Udang, $\mathrm{B}=$ tipe Cubadak, $\mathrm{C}=$ tipe Riau Gadang, dan D = tipe Riau Mancik

Hasil pengujian kadar katekin terhadap empat tipe tanaman gambir yang telah diamati memperlihatkan bahwa tipe Udang mempunyai kadar katekin yang lebih tinggi dibandingkan dengan tiga tipe lainnya. Oleh karena itu studi lanjut karakterisasi secara molekuler hanya dilakukan pada tanaman gambir tipe Udang

\subsubsection{Variasi Kadar Katekin pada Tipe Udang}

Kadar katekin pada tipe Udang juga mempunyai nilai yang cukup bervariasi, diantaranya ada yang memiliki kadar katekin lebih rendah yaitu 4,10\%, dan yang paling tinggi adalah 45, 87\% (Gambar 2).

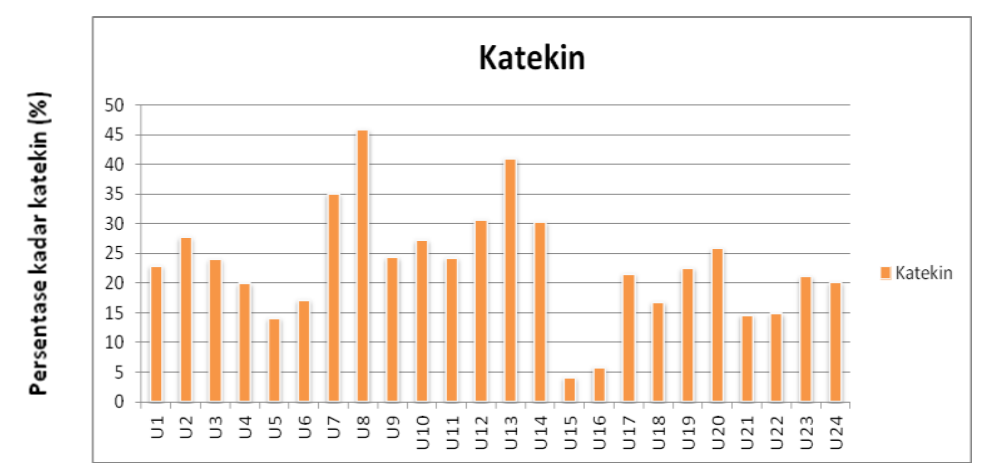

Gambar 2. Variasi kadar katekin pada 24 tanaman gambir tipe Udang.

\subsubsection{Hubungan Karakter Morfologi dengan Kadar Katekin}

Masing-masing karakter morfologi dikorelasikan terhadap nilai kadar katekin. Secara umum beberapa karakter tidak menunjukkan korelasi dengan kadar katekin., 
namun demikian ada lima karekter yang berkorelasi dengan kadar katekin yaitu, warna daun $\left(\mathrm{X}_{1}\right)$, warna cabang $\left(\mathrm{X}_{2}\right)$, warna buah muda $\left(\mathrm{X}_{3}\right)$, berat satu helai daun $\left(\mathrm{X}_{4}\right)$, dan rendemen hasil $\left(\mathrm{X}_{5}\right)$ dengan nilai $\mathrm{R}^{2}=0,7799$ dan peluang sangat nyata, yaitu $\mathrm{p}=0,0075$ untuk warna daun, dan warna buah muda dengan $\mathrm{p}=0,0249$. ditunjukkan dengan persamaan regresi sebagai berikut:

$$
Y=12,469+2,095 X_{1}+0,789 X_{2}+1,991 X_{3}-0,272 X_{4}-0,756 X_{5}
$$

\subsubsection{Struktur Anatomi Daun, dan Kadar Katekin pada Tipe Udang}

Struktur karakter anatomi daun pada tanaman gambir berpotensi katekin tinggi memperlihatkan nilai pengamatan beberapa karakter anatomi daun yang lebih tinggi daripada gambir berpotensi katekin rendah (Tabel 3).

Tabel 3. Rata-rata pengamatan anatomi daun gambir berpotensi katekin tinggi dan katekin rendah (masing-masing diwakili oleh 5 sampel tanaman)

\begin{tabular}{|c|c|c|c|c|c|c|c|c|}
\hline No & Sampel & $\begin{array}{c}\text { Tebal } \\
\text { kutikula } \\
\text { atas } \\
(\mu \mathrm{m})\end{array}$ & $\begin{array}{c}\text { Tebal } \\
\text { kutikula } \\
\text { bawah } \\
(\mu \mathrm{m})\end{array}$ & $\begin{array}{c}\text { Tebal } \\
\text { epidermis } \\
\text { atas }(\mu \mathrm{m})\end{array}$ & $\begin{array}{c}\text { Tebal } \\
\text { epidermis } \\
\text { bawah } \\
(\mu \mathrm{m})\end{array}$ & $\begin{array}{c}\text { Tebal } \\
\text { bunga } \\
\text { karang } \\
(\mu \mathrm{m})\end{array}$ & $\begin{array}{c}\text { Tebal } \\
\text { palisade } \\
(\mu \mathrm{m})\end{array}$ & $\begin{array}{l}\text { Tebal } \\
\text { daun } \\
(\mu \mathrm{m})\end{array}$ \\
\hline 1 & U7 & 3,0 & 1,2 & 12,1 & 8,8 & 56,3 & 105,8 & 196,3 \\
\hline 2 & U8 & 3,2 & 1,0 & 11,7 & 10,0 & 72,5 & 137,5 & 210,8 \\
\hline 3 & U12 & 2,3 & 3,3 & 13,3 & 9,2 & 62,9 & 105,4 & 183,3 \\
\hline 4 & U13 & 3,5 & 1,2 & 12,1 & 9,6 & 64,6 & 105,8 & 187,9 \\
\hline 5 & U14 & 3,2 & 2,0 & 13,3 & 8,3 & 75,0 & 121,7 & 232,9 \\
\hline \multirow[t]{2}{*}{$\mathbf{U t}$} & Total & 15,2 & 8,7 & 62,5 & 45,9 & 331,3 & 576,2 & 1011,2 \\
\hline & Rataan & 3,04 & 1,74 & 12,5 & 9,18 & 66,26 & 115,24 & 202,24 \\
\hline 6 & U5 & 3,0 & 1,0 & 13, & 8,8 & 53,3 & 105,4 & 190,4 \\
\hline 7 & U15 & 2,5 & 1,0 & 13,3 & 10,0 & 66,7 & 119,2 & 194,6 \\
\hline 8 & U16 & 2,0 & 1,0 & 12,9 & 7,9 & 60,0 & 108,3 & 193,3 \\
\hline 9 & $\mathrm{U} 21$ & 2,3 & 1,0 & 10,8 & 7,1 & 61,3 & 120,0 & 205,0 \\
\hline 10 & U22 & 2,7 & 1,0 & 11,3 & 8,3 & 60,4 & 125,0 & 212,1 \\
\hline \multirow[t]{2}{*}{$\mathbf{U r}$} & Total & 12,5 & 5,0 & 61,6 & 42,1 & 301,7 & 577,9 & 995,4 \\
\hline & Rataan & 2,5 & 1,0 & 12,32 & 8,42 & 60,34 & 115,58 & 199,08 \\
\hline
\end{tabular}

Ketebalan jaringan spons atau jaringan bunga karang pada kelompok gambir berpotensi kadar katekin tinggi rata-rata $66,26 \mu \mathrm{m}$. Angka tersebut lebih tebal daripada nilai rata-rata kelompok gambir berpotensi katekin rendah yaitu 60,34 $\mu \mathrm{m}$. 
Jaringan spons bentuknya tidak beraturan dan berfungsi untuk menyimpan cadangan makanan. Fenomena ini diduga bahwa spons yang lebih tebal akan lebih mampu menyimpan senyawa metabolit sekunder berupa getah gambir dalam jumlah yang lebih besar pada vakuolanya.

\subsection{Karakterisasi Molekuler}

\subsubsection{Isolasi DNA}

Sebelum dilakukan analisis untuk mendapatkan polimorfisme antara DNA tanaman gambir berpotensi kadar katekin tinggi dengan katekin rendah terlebih dahulu dilakukan isolasi DNA genom. Hasil isolasi dari 24 tanaman sampel semuanya menunjukkan kuantitas dan kualitas DNA yang baik, sebagiannya ditampilkan pada Gambar 3.

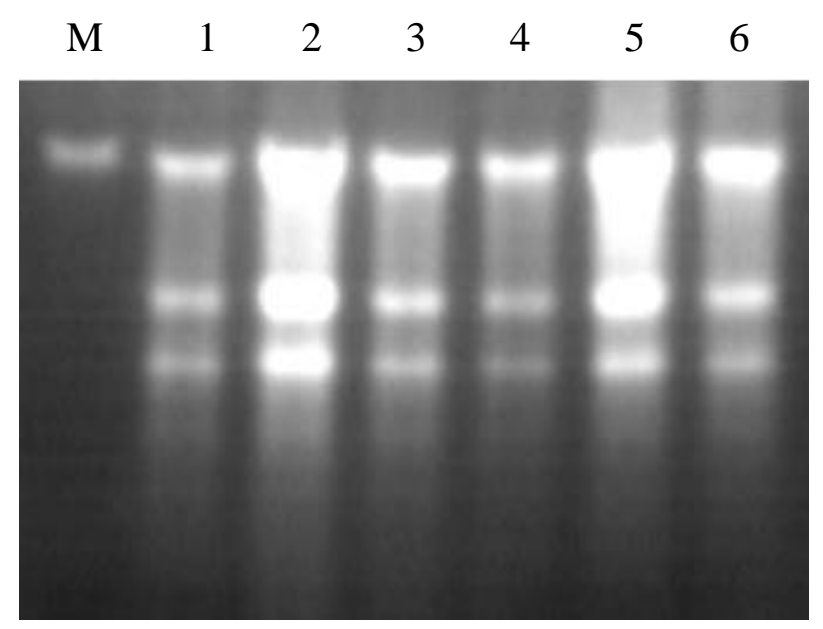

Gambar 3. Hasil isolasi DNA tanaman gambir . M= $\lambda$ DNA (50ng/ $\mu 1), 1$ - 6 adalah nomor sampel U1, U2, U3, U4, U5, dan U6. U= Tipe Udang

Hasil tersebut menggambarkan bahwa isolasi DNA gambir dengan menggunakan pucuk daun muda segar memakai metode CTAB (Doyle dan Doyle, 1990) pada tanaman gambir memberikan hasil yang sangat baik, karena jaringan masih lunak sehingga mudah membebaskan molekul-molekul asam nukleat dari inti sel. Bruce, et al., tahun 1992., cit. Jamsari dan Ferita, (2010) menyatakan bahwa prosedur lisis kimiawi yang mengandung deterjen seperti CTAB yang digabungkan dengan inkubasi pada suhu tinggi $\left(65^{\circ} \mathrm{C}\right)$ memiliki tujuan dalam meningkatkan efisiensi isolasi. 


\subsubsection{Differensiasi Fingerprinting RAPD}

Seleksi primer menggunakan pendekatan analisis segregasi bulked $(\mathrm{BSA}=$ Bulked Segregnat Analysis) pada pool DNA genom. Seleksi primer menggunakan 98 primer RAPD dari operon technology (Almaeda, USA). Analisis menggunakan primer RAPD tersebut, menghasilkan 6 primer (OPB-11, OPI-02, OPK-15, OPN-16, OPN-19, dan OPX-09 ) yang dapat memperlihatkan polimorfisme antara pool DNA gambir berpotensi katekin tinggi dengan gambir berpotensi katekin rendah. Secara umum fragmen-fragmen yang dihasilkan berkisar antara 1 hingga 5 pita, namun ada juga yang menghasilkan 8 fragmen DNA.Beberapa primer diantaranya bahkan tidak mampu menghasilkan fragmen (produk). Gambar 4 merupakan salah satu contoh polimorfisme yang ditunjukkan oleh primer OPK-15.

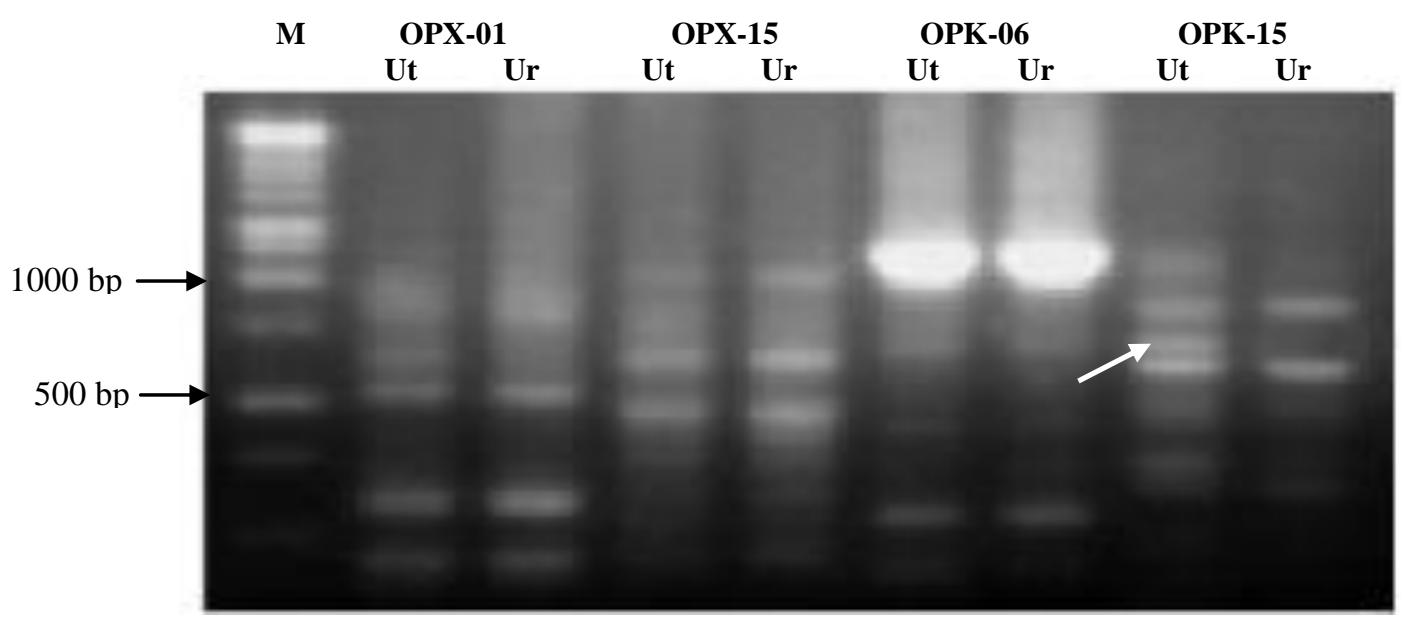

Gambar 4. Hasil amplifikasi PCR dengan primer OPX-01, OPX-15, OPK-06, dan OPK-15 pada sampel Udang katekin tinggi (Ut) dan Udang katekin rendah (Ur). $\mathrm{M}=1 \mathrm{~kb}$ ladder. Tanda panah adalah yang menunjukkan polimorfisme

Terjadinya polimorfisme antara gambir katekin tinggi dengan katekin rendah menggunakan penanda RAPD disebabkan oleh kemampuan sekuen primer acak tersebut menghasilkan produk sesuai dengan binding site yang kompatibel dengan DNA templet pada katekin tinggi, serta adanya sekuen tertentu yang keberadaannya dapat digunakan sebagai penciri kadar katekin pada gambir. 


\subsubsection{Seleksi Primer Tingkat Individu}

Enam primer RAPD yang telah terbukti menghasilkan polimorfisme antara DNA gambir katekin tinggi dengan katekin rendah diuji kembali pada masing-masing individu sampel penyusun pool. Hasil analisis keenam primer RAPD ini semuanya membentuk produk dengan beberapa ukuran, namun yang menunjukkan hasil yang stabil adalah primer OPK-15. Pengujian amplifikasi dengan PCR ternyata menghasilkan produk berukuran lebih kurang 700 bp (Gambar 5).

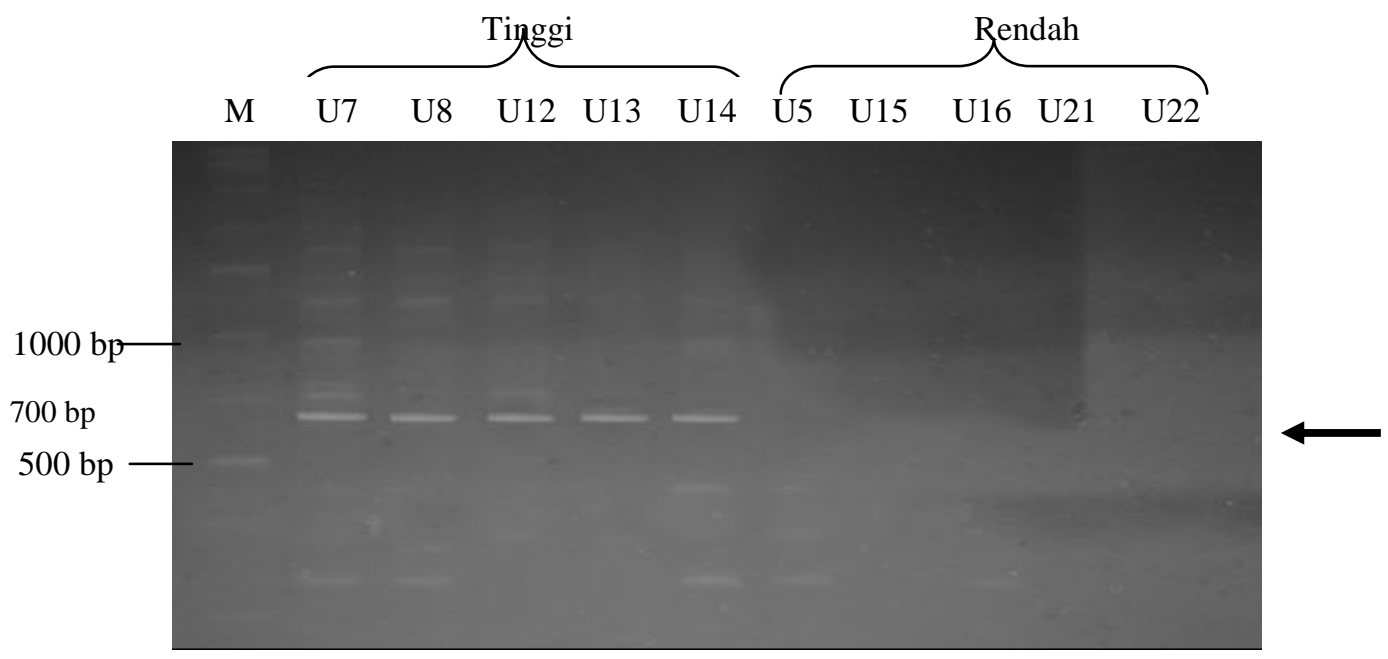

Gambar 5. Hasil amplifikasi PCR dengan primer OPK-15, dengan sampel U7, U8, U12, U13, U14, ( Udang katekin tinggi), dan U5,U15, U16, U21, U22 (Udang katekin rendah); $\mathrm{M}=1 \mathrm{~kb}$ ladder (Fermentas-USA). Tanda panah memperlihatkan posisi fragmen polimorfisme

Sebanyak 10 DNA sampel gambir yang diuji, memperlihatkan profil pita spesifik yang ditunjukkan oleh primer OPK-15, yakni memberikan produk pada Udang katekin tinggi dengan ukuran sekitar 700 bp, namun tidak dijumpai pada gambir Udang katekin rendah. Untuk mendapatkan fragmen target hasil seleksi yang berasal dari primer RAPD memang memerlukan pengujian berulang sampai ditemukan fragmen yang dianggap spesifik dibandingkan dengan fragmen lainnya. Pita-pita spesifik ini dapat memberi harapan sebagai penanda (marker) gambir berpotensi katekin tinggi. Fargmen spesifik yang telah diperoleh dengan primer OPK-15 tersebut dipurifikasi dan digunakan untuk kegiatan selanjutnya yaitu kloning, dan sekuensing. 


\subsection{Kloning Fragmen RAPD Spesifik Penciri Kadar Katekin Tinggi}

DNA hasil purifikasi selanjutnya digunakan untuk kegiatan ligasi dan transformasi menggunakan vektor plasmid pGem T-Easy dengan bantuan bakteri E.coli strain DH5a. Kloning dilakukan dengan tujuan memperbanyak DNA yang tersisip pada sel kompeten (E.coli). Untuk dapat mengamati keberhasilan transformasi dihitung efisiensi transformasi.

\subsubsection{Efisiensi Transformasi}

Bukti keberhasilan transformasi dilakukan pada klon-klon yang ditumbuhkan dalam cawan petri yang mengandung media selektif ( ditambah IPTG, X-gal, dan ampisillin) berdasarkan warna (blue-white selection). Jumlah koloni rekombinan yang dihitung secara acak masing-masing sampel pada enam buah cawan petri, didapatkan persentase rata-rata koloni putih $88,1 \%$, dan koloni biru $0,7 \%$, ada juga sekitar $\pm 11,2$ \% koloni bakteri berwarna putih kusam yang juga resisten terhadap ampisilin. Terbentuknya koloni putih, disebabkan karena gen $L a c-Z$ yang semestinya berfungsi merubah senyawa $X$-Gal menjadi berwarna biru, tidak lagi mampu melaksanakan tugas oleh karena sudah diinterupsi oleh fragmen RAPD yang disisipkan. Gen Lac-Z mengkode enzim $\beta$-galaktosidase yang mengkatalisis pemecahan laktosa menjadi glukosa dan galaktosa.

\subsubsection{Isolasi Plasmid DNA Rekombinan}

Hasil isolasi DNA plasmid rekombinan seperti terlihat pada Gambar 6. Isolasi plasmid berhasil dilakukan, karena dibuktikan oleh panjang fragmen DNA yang dihasilkan lebih dari ukuran awal plasmid pGem T-easy (3.015 bp). Sampel lain yaitu U8, U12, U13, dan U14 hasil isolasi plasmid DNA rekombinannya cukup bagus (gambar tidak ditampilkan).

Berdasarkan hasil isolasi DNA plasmid rekombinan yang diperoleh, maka dapat dipastikan bahwa semua koloni tersebut mengandung fragmen RAPD yang disisipkan. Meskipun melalui analisis ini belum bisa diprediksi secara akurat berapa basa ukuran insersi fragmen RAPD yang berhasil diselipkan sebenarnya. Hasil yang lebih akurat dapat dibuktikan dengan melakukan amplifikasi PCR menggunakan primer T7 dan SP6, yaitu primer universal pGemT easy. 


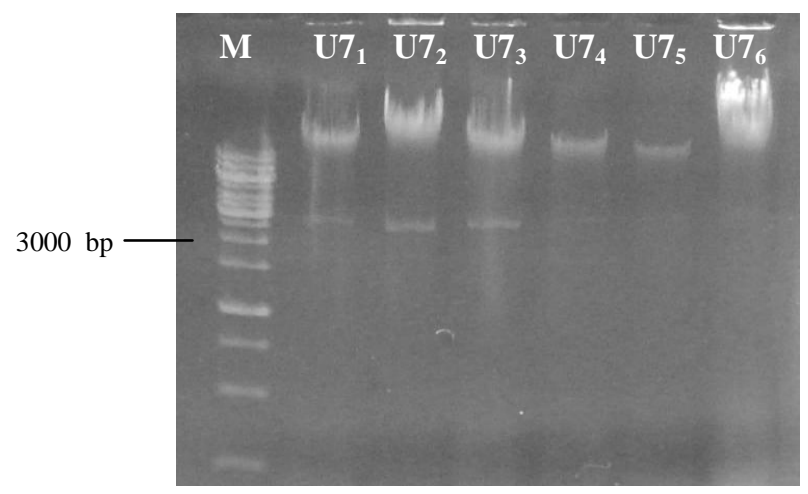

Gambar 6. Hasil isolasi DNA plasmid. $(\mathrm{M}=$ marker $1 \mathrm{~kb}$ ladder

Fermentas-USA); U7 1 s/d. U7 6 adalah sampel Udang 7

Dari seluruh kegiatan isolasi plasmid DNA rekombinan, diperoleh persentase rata-rata koloni yang menghasilkan plasmid sekitar 59,6\%, dan yang tidak mengandung plasmid 40,4\%. Angka 59,6\% ini memperlihatkan nilai yang lebih tinggi dari penelitian Jamsari (2008) dengan rata-rata menghasilkan plasmid 47,6\% untuk $C$. gloesporides dan $45 \%$ untuk $C$. capsici

\subsubsection{Analisis Fragmen Insert dengan Primer T7 dan SP6}

Hasil amplifikasi DNA plasmid sampel U14 dengan menggunakan pasangan primer T7 dan SP6 dapat dilihat pada Gambar 7. Sampel yang lain (U7, U8, U12, dan U13) cukup bagus dan berhasil membentuk fragmen dengan ukuran rata-rata $400 \mathrm{bp}$. Kegiatan amplifikasi PCR dengan primer T7 dan SP6 terhadap 5 sampel tanaman gambir berpotensi kadar katekin tinggi, juga dilakukan pada koloni biru muda terang. Hasilnya menunjukkan fragmen yang terbentuk cukup pendek yaitu kira-kira $250 \mathrm{bp}$. Terbentuknya koloni biru disebabkan karena gen lac-Z masih berekspresi dan menghasilkan enzim $\beta$-galaktosidase, dimana enzim ini akan memecah X-gal dan menghasilkan senyawa berwarna biru, Hal ini bisa saja terjadi karena kemungkinan fragmen yang diselipkan tidak terlalu panjang (kurang dari satu kb). 


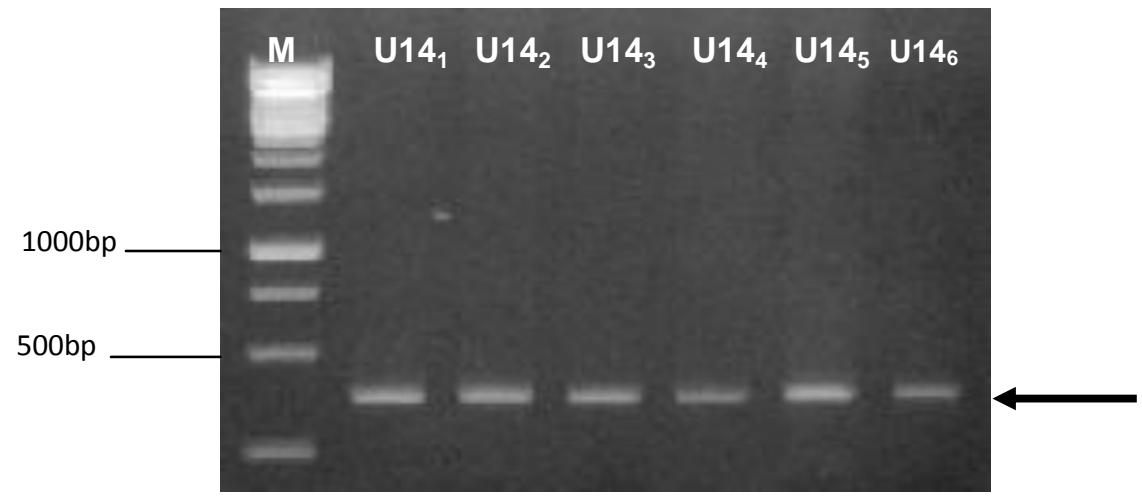

Gambar 7. Hasil amplifikasi PCR dengan primer T7 dan SP6 $(M=$ marker 1 kb ladder Fermentas-USA); U14 ${ }_{1}$ s/d. U14 6 adalah sampel Udang 14 Tanda panah adalah fragmen insert

Bila dibandingkan fragmen hasil RAPD dengan fragmen hasil amplifikasi dengan primer T7dan SP6 tidak selalu konsisten. Fragmen hasil amplifikasi dengan primer RAPD sebelum diklon berukuran kira-kira 700 bp, dan setelah diklon fragmennya berukuran kira-kira $400 \mathrm{bp}$.

Sistem penanda RAPD mempunyai kelemahan sehubungan dengan hasil yang kurang konsisten. Sebagaimana yang dikemukakan oleh Yu dan Pauls, (1992) menyatakan bahwa banyak faktor yang mempengaruhi ketidakstabilan dan sensitifitas penanda RAPD seperti rasio templet DNA dan primer, konsentrasi ion Mg dan TaqPolymerase yang digunakan dan jenis mesin PCR yang dipakai. Hal yang sama telah dikemukakan oleh beberapa peneliti sebelumnya (Meunier and Grimont, 1993; Rajput, et al., 2006; Jamsari, 2008) bahwa produk RAPD memang tidak stabil.

Berkaitan dengan fungsinya sebagai Marker Asisted Selection (MAS), penanda RAPD yang sudah terbukti terkait dengan sifat tertentu dapat dikonversi kedalam sistem sequens characterize amplified region (SCARs) (Paran, et al, 1998), serta sistem STS dan CAPs. Pada penelitian ini penanda RAPD dikonversi ke sistem penanda STS (Sequence Tagged Sites) yaitu sistem penanda yang sudah berbasis pada informasi sekuen DNA.

\subsubsection{Sekuensing DNA Fragmen Spesifik}

Hasil sekuensing yang diperoleh yaitu berupa elektrophoregram dengan peakpeak (puncak) yang mempunyai warna-warni untuk membedakan jenis basa 
nukleotidanya. Nukleotida A (Adenin) berwarna hijau, nukleotida G (Guanin) berwarna hitam, nukleotida T (Timin) berwarna merah, dan nukleotida C (Citosin) berwarna biru. Pola warna peak-peak tersebut juga sama dengan pola warna yang dikemukakan oleh Ratnayani, et al (2007).

Gambar 8 memperlihatkan bahwa sampel U13=347bp, dan U14 = 314 bp. Sampel yang lain, U7 mempunyai panjang sekuens nukleotida 445bp, U8= 402 bp, U12=349bp (gambar tidak ditampilkan). Dengan demikian total pajang sekuens yang dianalisis pada 5 fragmen sampel tanaman gambir berpotensi kadar katekin tinggi adalah 1857 bp dengan rata-rata panjang sekuens 371 bp. Jika diperhatikan puncak peak dari elektroporegram di atas, dapat dinyatakan bahwa hasil sekuensing berupa urutan nukleotidanya cukup bagus.

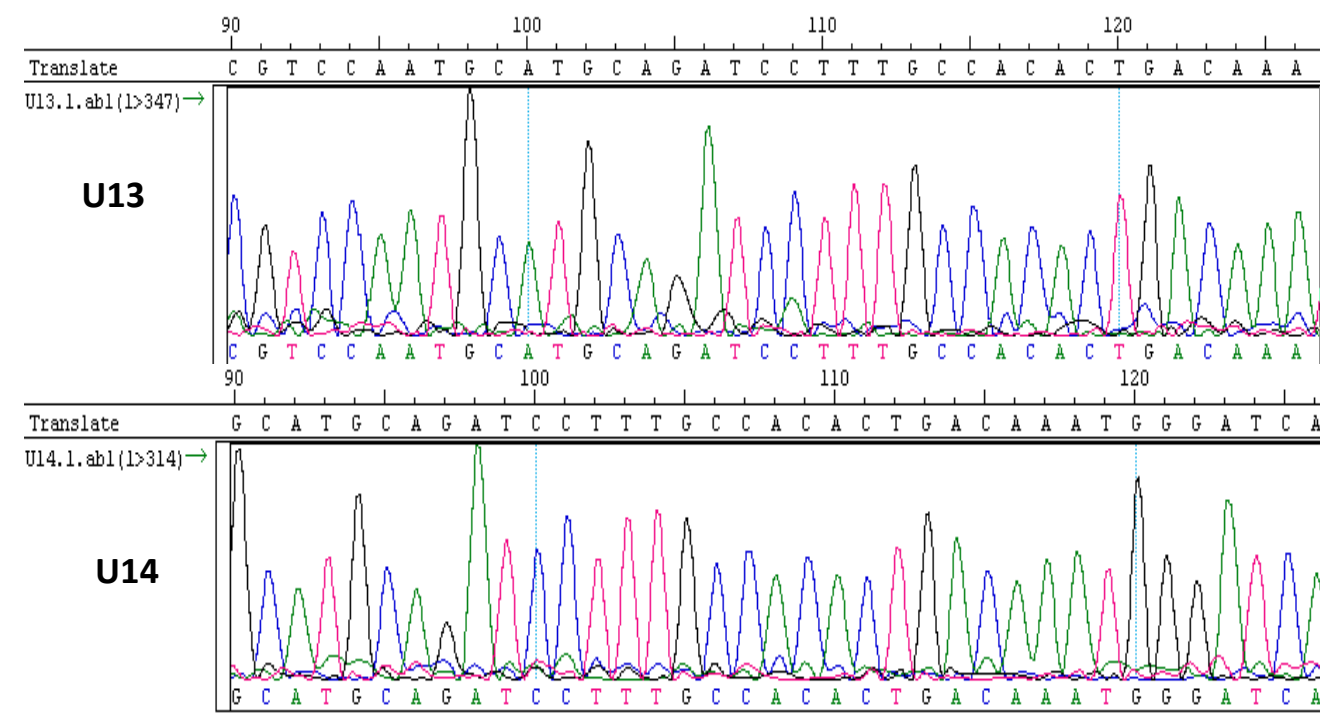

Gambar 8. Visualisasi sebahagian elektrophoregram sekuen DNA fragmen U13, dan U14 (gambir Udang berpotensi kadar katekin tinggi). Adenin= hijau, Guanin $=$ hitam, Timin $=$ merah, dan Citosin $=$ biru,

Sekeuns DNA yang diperoleh masih tergabung dengan sekuen palsmid (vektor). Untuk memisahkan sekuen plasmid (vektor) yang telah digunakan dalam transformasi, dan untuk menentukan seberapa panjang sekuen insert (panjang fragmen sisipan), telah dilakukan analisis dengan vectorscreen (Gambar 9) 
U14.1
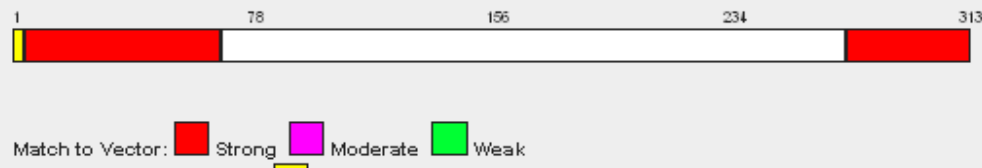

Segment of suspect origin:

Segments matching vector:

Strong match: 467,274313 Suspect origin: $1 \cdot 3$

Gambar 9. Hasil vektor screening sekuen DNA gambir berpotnsi kadar katekin tinggi, diwakili oleh U14.

Gambar 9 memperlihatkan hasil analisis vecsreen sampel U14 tanaman gambir berpotensi kadar katekin tinggi. Warna merah adalah sekuens plasmid, dan warna putih adalah sekuen insert (fragmen spesifik), sedangkan warna kuning merupakan pengotor, yang terikut saat melakukan kegiatan kloning. Hasil vector screening (Gambar 9) menunjukkan bahwa fragmen target yang berhasil ditransformasikan menggunakan vektor plasmid pGem T-Easy dengan bantuan bakteri E.coli strain DH5 $\alpha$, untuk gambir berpotensi kadar katekin tinggi berukuran 206 bp - 294 bp.

Hasil penjajaran sekuens 5 sampel Udang katekin tinggi (U7, U8, U12, U13, dan U14) dengan program ClustalW2, diantara sesama sampel memperlihatkan perbedaan pada sekuensnya. Peristiwa insersi, delesi dan subsitusi terjadi pada basabasa DNA untuk kelima sampel tersebut. Peristiwa indel yang terjadi sangat bervariasi, ada yang hanya 1 (satu) basa saja bahkan pada tempat tertentu ada yang mengalami indel sebanyak 16 basa. Peristiwa subsitusi terjadi 1-3 basa DNA saja. Untuk kelima sampel gambir berpotensi katekin tinggi ini terdapat perbedaan sekuen DNA yang disebabkan oleh insersi, delesi dan substitusi.

Hasil analisis BLAST dari masing-masing sekuen DNA yang telah diklon pada E.coli DH5 $\alpha$ yang dibandingkan dengan sekuen data GenBank, tidak ditemukan data sekuen yang telah didepositkan di Genbank terutama yang sefamili dengan Unacaria. Hasil Blast memperlihatkan bahwa sekuen DNA gambir mempunyai homologi dengan Oryza sativa Japonica Group Chromosome 10 clone dengan total skor 338, Query coverage 95\%, E-value 7e-90, dan Max-ident 97\%. Hal ini diduga karena 
sekuen DNA gambir yang dibandingkan cukup pendek, sehingga sebahagian dari sekuen pendek tersebut keberadaan sekuennya mirip dengan Oryza sativa Japonica. Hasil tersebut dapat dipahami bahwa sekuen hasil penelitian merupakan DNA struktural (klon DNA genomik) yang mungkin terdapat disekitar gen yang terlibat dalam penentu kadar katekin. Meskipun sekuen tersebut bukanlah gen, namun basabasa dari semua sekuen DNA tersebut dapat digunakan sebagai penanda (marker) pada tanaman gambir yang berpotensi katekin tinggi. Sehubungan dengan spesifikasi ekspresi gen pengendali biosintesis katekin belum diketahui pada penelitian ini, maka untuk memastikan hal tersebut diperlukan penelitian lebih lanjut

\subsection{Desain Primer Spesifik Terkait Potensi Kadar Katekin Tinggi}

Primer didesain berdasarkan sekuen DNA yang diperoleh pada tahap sebelumnya. Desain primer dilakukan menggunakan program Primer3 yang diakses secara on line di internet (http://frodo.wi.mit.edu/primer3/, 2011). Sekuen primer tersebut seperti yang ditampilkan pada Tabel 4.

Tabel. 4. Sekuen primer yang didesain dengan program Primer3

\begin{tabular}{lccc}
\hline No & $\begin{array}{c}\text { Nama } \\
\text { Primer }\end{array}$ & Urutan Sekuens & $\begin{array}{c}\text { Prediksi } \\
\text { Panjang Produk }\end{array}$ \\
\hline 1 & Udtg1 & 5'- CCAACCAAATGAGGCCCTA & \multirow{2}{*}{ 246 bp } \\
& Udtg2 & 5'- AATGAGCACGCAAAATCAAA & \\
\hline 2 & Udtg3 & 5'- CAGATCCTTTGCCACACTGA & \multirow{2}{*}{$178 \mathrm{bp}$} \\
\hline
\end{tabular}

Pengujian primer Udtg1 dan Udgt2 diuji pada DNA genom awal, belum menunjukkan hasil/produk. Sedangkan pengujian kombinasi primer Udtg3 dan Udtg4 ternyata mampu menghasilkan produk sesuai harapan terhadap genom awal. Namun dari beberapa kali pengujian untuk kombinasi tersebut masih belum menunjukkan akurasi $100 \%$, karena masih dijumpai fragmen produk amplifikasi pada satu sampel DNA Udang katekin rendah (tidak sesuai harapan). Pada sampel Udang U15, U16, U21, dan U22 (gambir berpotensi katekin rendah) yang diuji dengan kombinasi primer Udtg3 dan Udtg4, tidak mampu menghasilkan produk. (berarti sesuai dengan harapan) (Gambar 10). 


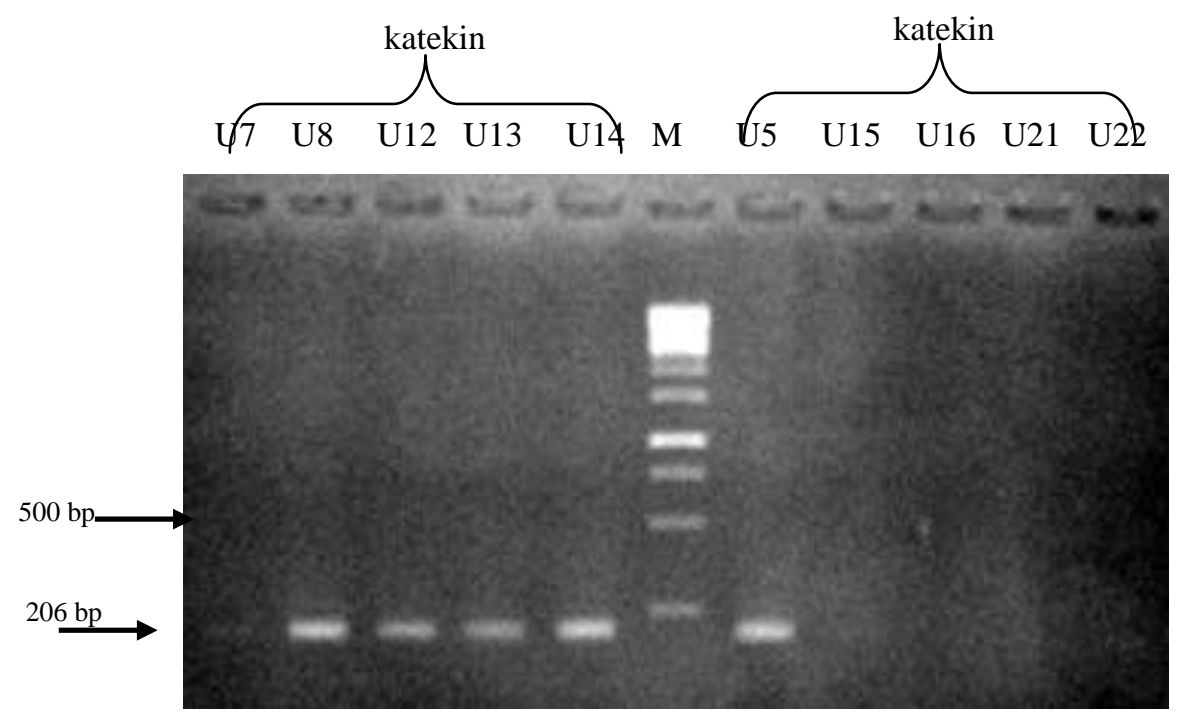

Gambar 10. Amplifikasi PCR dengan kombinasi primer Udtg3 dan Udtg4 [10 $\mathrm{pmol} / \mathrm{ul}$ ] pada DNA genom awal tipe Udang katekin tinggi (U7,U8,U12,U13,U14) dan Udang katekin rendah (U5, U15, U16, $\mathrm{U} 21, \mathrm{U} 22$

Sampel U7 memperlihatkan intensitas fragmen sangat tipis. Hal tersebut diduga disebabkan oleh tingkat kemurnian DNA yang rendah atau jumlah salinan fragmen tersebut sangat sedikit. Mollah, et al., (2004) menyatakan bahwa, bervariasinya intensitas fragmen DNA hasil amplifikasi ini disebabkan oleh tingkat kemurnian DNA yang tidak sama, jumlah copy gen atau afinitas primer dengan templet yang berbeda-beda.

\subsection{Uji Akurasi Sistem Penanda Molekuler (STS)}

Hasil amplifikasi PCR menggunakan kombinasi primer Udtg3+Udtg4 terhadap 24 DNA gambir dapat dikemukakan bahwa, beberapa sampel DNA katekin tinggi belum mampu menghasilkan produk sesuai harapan, demikian juga untuk sampel DNA katekin rendah ditemui pada dua individu yang masih menghasilkan fragmen ( fragmen tidak sesuai harapan). Pengujian kombinasi primer spesifik hasil didesain untuk mendeteksi DNA gambir berpotensi katekin tinggi tingkat keberhasilannya rendah atau tingkat akurasi primer ini masih rendah.

Tingkat akurasi yang rendah kemungkinan disebabkan karena produksi kadar katekin merupakan karakter kuantitatif yang dikendalikan oleh banyak gen. Dalam 
kromosom, banyak lokus yang menentukan karakter tersebut, tetapi belum diketahui lokus mana yang berperan. Kemungkinan posisi fragmen penanda (marker) terletak sangat jauh, sehingga saat dilakukan amplifikasi dengan kombinasi primer spesifik tersebut tidak mampu menghasilkan produk PCR. Bila diperhatikan dari asal usul bahan genetik yang digunakan untuk penelitian, berasal dari genotipe populasi yang berbeda-beda sehingga diduga ada kemungkinan mempunyai variasi genotipe yang luas.

\section{KESIMPULAN DAN SARAN}

Berdasarkan data hasil pengamatan pada percobaan ini dapat diambil beberapa kesimpulan:

1. Warna daun merah dan tebal daun (struktur anatomi) merupakan karakter yang mencirikan tanaman gambir berpotensi kadar katekin tinggi.

2. Sekuen fragmen target yang terkait potensi kadar katekin tinggi telah berhasil disisipkan berjumlah 206 nukleotida.

3. Kombinasi primer spesifik dengan kode Udtg3 (5'- CAGATCCTTTGCC ACACTGA -3') dan Udtg4 (5'- CCTGCCAACATAACAGCGTA - 3') telah berhasil didesain dari sekuen DNA yang diperoleh.

4. Dihasilkan sistem metode deteksi dini dalam kegiatan seleksi tanaman gambir yang terkait potensi genetik kadar katekin tinggi secara molekuler menggunakan kombinasi primer spesifik Udtg3 dan Udtg4.

\subsection{Saran}

1. Agar primer Udtg3 dan Udtg4 dapat diketahui kemampuan akurasinya, diperlukan pengujian tingkat akurasi pada beberapa sampel daerah sentra produksi gambir di Sumatera Barat.

2. Perlu dilakukan penelitian lebih lanjut, antara lain ; a) menentukan gen spesifik yang mengendalikan / terpaut kuat dengan potensi genetik kadar katekin tinggi dan katekin rendah, b) identifikasi lebih lanjut sehubungan dengan gen-gen penting yang menentukan produksi tinggi, dalam upaya perakitan kultivar unggul tanaman gambir 


\section{DAFTAR PUSTAKA}

Babaloka O. O. 2003. Minireview: Molecular Techniques: an Overview of Methods for the Detection of Bacteria. African Journal of Biotechnology vo.2 (12): 710-713.

Badan Pusat Statistik. 2010. Sumatera Barat dalam angka. Badan Pusat Statistik. Jakarta.

Birnboim ,H. Cand\& J. Doly . 1979. A rapid alkaline extraction procedure for screening recombinant plasmid DNA. Nucl. Acid. Res. 7:1513-23. Laboratoirede Génétique Moléculaire, Institut de Recherche en Biologie Moléculaire, Paris, France

Denian. A., H. Idris, dan E. Suryani. 1992. Studi sifat-sifat morfologis beberapa tipe gambir di Sumatera Barat. Bul. Litro VII(2) : 21-25.

Dinas Perkebunan Sumatera Barat. 1998. Statistik Perkebunan. Dinas Perkebunan Sumatera Barat. Padang

Doyle, J.J. and J.L. Doyle. 1987. Isolation of plant DNA from fress tissue. Focus 12: 13-15.

Fauza, H. 2009. Identifikasi Karakteristik Gambir (Uncaria spp.) di Sumatera Barat dan Analisis RAPD. Disertasi. Universitas Padjadjaran Bandung. (Tidak dipublikasikan).

Fauza, H., Murdaningsih, H.K., E.Suryani, dan I. Ferita. 2010. Sinergi teknik molekuler dan pemuliaan tanaman dalam perakitan kultivar unggul tanaman gambir tipe Udang berdaya hasil tinggi dan kandungan katekin tinggi. Laporan Penelitian Skim KKP3T Fakultas Pertanian Universitas Andalas bekerjasama dengan Badan Penelitian dan Pengembangan Pertanian. Padang 81 hal.

Hasan, Z., A. Denian, Iran, A.J.P. Tamsin, dan B.Burhaman. 2000. Budidaya dan pengolahan Gambir. BPTP. Sukarami. 29 hal

http:// biomol.Word press.com/ bahan-ajar/sekuensing-dna2011 [20 Januari 2011]

http://frodo.wi.mit.edu/primer3/2011 [ 20 Januari 2011]

Jamsari, I.Nitzt,S.M. Reamon-Buttner, C.Jung. 2004. The use of BAC-based large insert library for development of gender diagnostic marker in asparagus (Asparagus officinalis L.) Theor and Appl. Genet. Vol.108:1140-1146

Jamsari, 2008. Preparasi DNA Spesies Colletotrichum sp. dan Spesifitas Sistem Fingerprinting RAPD. Jurnal Natur Indonesia 11: 31-39. 
Jamsari dan I.Ferita, 2010. Pengembangan Metode Preparasi DNA Cepat, Hibridisasi DNA Genomik-Produk PCR dan Visualisasinya untuk Mendukung Sistem Deteksi Dini Pathogen Antraknosa pada Pertanaman Cabai. Laporan Hibah Bersaing tahun Anggaran 2010. Padang 51 hal

Lee, I. M., I. M. Bartoszyk, D. E. Gundersen, B. Mogen, and R. E. Davis. 1997. Nested PCR for Ultrasensitive Detection of the Potato Ring Rot Bacterium, Clavibacter michiganensis subsp. Sepedonicus. Applied and environmental microbiology vol. 63 No. 7: 2625-2630.

Lefebv re, V., B. Goffinet, J. Chauvet, B. Caromel, P. Signoret, R. Brand, and A. Palloix. 2001. Evaluation of genetic distance between pepper inbred lines for cultivar protection purpose : comparison of AFLP, RAPD, and phenotypic data. Theor. Appl. Genet. 102 : 741-750

Lopez, M.M., E. Bertolini, A. Olmos, P. Caruso, M.T. Gorris, P. Llop, R. Penyalver, and M. Cambra. 2003. Innovative Tools for Detection of Plant Pathogenic Viruses and Bacteria. Int Microbiol 6: 233-243

Meunier, J.R, Grimont, P.A. 1993. Factors affecting reproducibility of random amplified polymorphic DNA fingerprinting. Res. Microbiol. 144: 373-379.

Mollah, S. Jaya, Abdul., Aswidinnoor, Hajrial \& Santoso, Djoko. 2004. Deteksi dan Analisis Sekuens Gen Inhibitor Proteinase pada Beberapa Klon Kakao Harapan Tahan Penggerek Buah Kakao dari Sulawesi Selatan. Menara Perkebunan. 72(1):1-10.

Paran, I., E.Aftergoot, and C.Shifriss. 1998. Variation in Capsicum annum revealed by RAPD and AFLP markers. Euphytica. 99: 167 - 173.

Pastrik, K. H. and F. A. Rainey. 1999. Identification and Differentiation of Clavibacter michiganensis subspecies by Polymerase Chain Reaction-Based Techniques. J. Phytopathology 147: 687-693.

Paterson,A.H,S.D. Tanskley and M.E. Soller. 1991. DNA marker in plant improvement. Advancer in agronomy. (44) : p39-44

Promega (1999). pGEM®-Tand pGEM®-T Easy Vector Systems (Technical Manual

Qi, X and P.Lindhout. 1997. Development of AFLP markers in barley . Mol. Gen. Genet. 254: $330-336$.

Rajput, S.G., Wable, K.J., Sharma, K.M., Kubde, P.D. and Mulay, S.A. 2006. Reproducibility testing of RAPD and SSR markers in Tomato. African Journal of Biotechnology 5: 108-112. 
Ratnayani, K., I.Nengah Wirajana, dan A.A.I.A.M. Laksmiwati. 2007. Analisis Variasi Nukleotida Daerah D-loop DNA Mitokondria pada Suatu Individu Suku Bali Normal. Jurusan Kimia FMIPA Universitas Udayana Bukit Jimbaran Bali.

Roswita, D. 1990. Prospek tanaman gambir di Sumatera Barat. Bul. BIP Padang (01): 8-10.

Sambrook, J. and D.W. Russell, 2001. Molecular cloning; A laboratory Manual, 3rd edition, Cold spring Harbor laboratory Press, New York, pp: 1.31-1.38, 1.1161.118

SP-SMP-377-1985. Penentuan kadar katechin dari gambir. Hal: 122-126.

Tjitrosoepomo, G. 2005. Taksonomi Umum, Dasar-Dasar Taksonomi Tumbuhan. Gajah Mada University Press. 216 hal.

Yang, W., A.C. de Olivera., I.Godwin., K. Schertz, and J.L. Bennetzen. 1996. Comparison of DNA markers technologies in characterizing plant genome diversity. Variability in Chinese Shorgums. Crop. Sci. 36 : 1669-1676

Yu, K., K.P. Pauls. 1992. Optimization of the PCR program for RAPD analysis. Nucl. Acids Res. 20: 2606. 